MEMOIRS AND REFLECTIONS 
PATRONS OF THE SOCIETY

Blake, Cassels \& Graydon LLP

Gowlings

Lax O'Sullivan Scott Lisus LLP

McCarthy Tétrault LLP

Osler, Hoskin \& Harcourt LLP

Paliare Roland Rosenberg Rothstein LLP

Torkin Manes LLP

Torys LLP

WeirFoulds LLP

The Osgoode Society is supported by a grant from

The Law Foundation of Ontario.

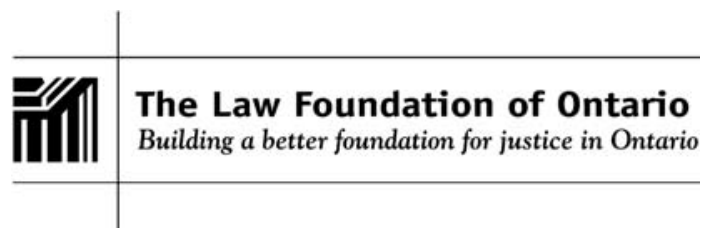

The Society also thanks The Law Society of Upper Canada for its continuing support. 


\section{MEMOIRS AND \\ REFLECTIONS}

ROY MCMURTRY

Published for The Osgoode Society for Canadian Legal History by University of Toronto Press

Toronto Buffalo London 
(C) Osgoode Society for Canadian Legal History 2013

www.utppublishing.com

www.osgoodesociety.ca

Printed in Canada

ISBN 978-1-4426-4830-2

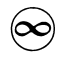

Printed on acid-free, 100\% post-consumer recycled paper with vegetable-based inks.

Publication cataloguing information is available from

Library and Archives Canada.

University of Toronto Press acknowledges the financial assistance to its publishing program of the Canada Council for the Arts and the Ontario Arts Council.

Canada Council for the Arts
Conseil des Arts du Canada

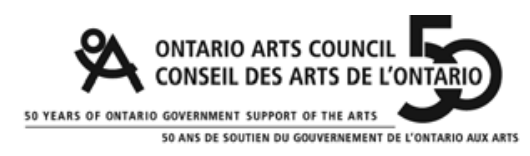

University of Toronto Press acknowledges the financial support of the Government of Canada through the Canada Book Fund for its publishing activities. 
To my wife, Ria, and our family, who have been the bedrock of my life 
This page intentionally left blank 